\title{
AIR TEMPERATURE FIELD DEFORMATION UNDER THE INFLUENCE OF BUILT-UP AREA IN WARSAW
}

This paper is aimed at the separation of the influence of artificial active surfaces on air temperature from its natural changes.

The solution to this problem is presented on the example of Warsaw, - a lowland town, situated in the climatic zone of temperate latitudes $\left(\varphi=52.1^{\circ}, \lambda=21.0^{\circ}, H=106 \mathrm{~m}\right)$.

Investigations of the influence of land development on the temperature field have been carried out in various spatial scales of the entire town, parts of town with compact and dispersed development, and park areas in the centre of the town. The average value calculated from data obtained from meteorological stations located in the surroundings (the so-called background) was accepted as the reference point in our consideraions.

Data from stations of the Institute for Meteorology and Water Management, as well as results of measurements carried out in the Department of Climatology of the University of Warsaw during the period 1961-1965 constituted source materials.

Air temperature differences in and outside of town and their dependence on the state of the atmosphere were accepted as measures of the relation between air temperature and the influence of the town.

The determination of the rate of warming up and cooling down of urban areas, and the times of occurrence and disappearence of the urban heat island is of great cognitive significance. Of importance are also threshold values of such parameters as air temperature, cloudiness and wind velocity, at which deformation of the air temperature field is the greatest one.

The relationship between a built-up area and the air temperature field depends mainly on the time of the day and season of the year. It is described by sinusoids determined for the entire town, certain parts of the town with dense and scarce building development and complexes of parks (Tables 1-3, Fig. 1, 2).

There is a regularity which says that differences of the average minimum $\left(\Delta T_{\text {min }}\right)$ and mean daily $(\Delta T)$ air temperature between town and its surroundings are positive during the entire year, and differences of the mean 
Table 1

Sinusoids of annual differences of average $(\Delta T)$, maximum $\left(\Delta T_{\max }\right)$, minimum $\left(\Delta T_{\min }\right)$ air temperature and daily temperature amplitude $(\Delta A)$ between town and its vicinity $(1961-1965)$, $t$ - calendar day, $R$ - coefficient of multiple correlation

\begin{tabular}{|c|c|c|c|}
\hline Type of area & & $\Delta y=a+b \sin \left(\frac{2 \pi}{365,25} t+c\right)$ & $\boldsymbol{R}$ \\
\hline Town & $\begin{array}{l}\Delta T= \\
\Delta T_{\max } \\
\Delta T_{\min }= \\
\Delta A=\end{array}$ & $\begin{array}{r}0.064+0.139 \sin (0.0172 t-1.952) \\
0.064+0.146 \sin (0.0172 t+0.580) \\
1.097+0.564 \sin (0.0172 t+1.933) \\
-1.074+1.225 \sin (0.0172 t+1.047)\end{array}$ & $\begin{array}{l}0.48 \\
0.54 \\
0.64 \\
0.72\end{array}$ \\
\hline Dense development & $\begin{array}{l}\Delta \mathrm{T}= \\
\Delta T_{\max }= \\
\Delta T_{\min }= \\
\Delta A=\end{array}$ & $\begin{array}{r}0.867+0.149 \sin (0.0171 t-2.157) \\
0.090+0.253 \sin (0.0172 t+0.850) \\
1.436+0.495 \sin (0.0172 t-1.992) \\
-1.346+0.740 \sin (0.0172 t+1.050)\end{array}$ & $\begin{array}{l}0.64 \\
0.71 \\
0.82 \\
0.76\end{array}$ \\
\hline Scarce development & $\begin{array}{l}\Delta T= \\
\Delta T_{\max }= \\
\Delta T_{\min } \\
\Delta A=\end{array}$ & $\begin{array}{r}0.392+0.115 \sin (0.0172 t-2.659) \\
0.050+0.078 \sin (0.0172 t-0.364) \\
0.852+0.355 \sin (0.0172 t-1.880) \\
-0.802+0.359 \sin (0.0172 t+1.044)\end{array}$ & $\begin{array}{l}0.48 \\
0.58 \\
0.78 \\
0.68\end{array}$ \\
\hline Park complexes & $\begin{array}{l}\Delta T= \\
\Delta T_{\max }= \\
\Delta T_{\min }= \\
\Delta A=\end{array}$ & $\begin{array}{r}0.755+0.044 \sin (0.0172 t-1.492) \\
0.441+0.162 \sin (0.0172 t-0.396) \\
1.001+0.302 \sin (0.0172 t-2.031) \\
-0.559+0.351 \sin (0.0172 t+0.642)\end{array}$ & $\begin{array}{l}0.31 \\
0.69 \\
0.80 \\
0.74\end{array}$ \\
\hline
\end{tabular}

Table 2

Deformation of the air temperature field in the urban areas according to differences of average $(\Delta T)$, maximum $\left(\Delta T_{\max }\right)$, minimum $\left(\Delta T_{\min }\right)$ air temperature and daily temperature amplitude $(\Delta A)$ with relation to its vicinity

\begin{tabular}{|c|c|c|c|c|c|}
\hline Type of area & $\begin{array}{c}\text { Extre- } \\
\text { mes }\end{array}$ & $\Delta T$ & $\Delta T_{\max }$ & $\Delta T_{\min }$ & $\Delta A$ \\
\hline Town & $\begin{array}{l}\text { Max } \\
\text { Min }\end{array}$ & $\begin{array}{l}0.8 \text { VII } \\
0.5 \text { I }\end{array}$ & $\begin{aligned} 0.2 & \text { II } \\
-0.1 & \text { VIII }\end{aligned}$ & $\begin{array}{l}1.7 \text { VII } \\
0.5 \mathrm{I}\end{array}$ & $\begin{array}{l}-1.7 \text { VIII } \\
-0.3 \text { II }\end{array}$ \\
\hline $\begin{array}{l}\text { Dense } \\
\text { development }\end{array}$ & $\begin{array}{l}\text { Max } \\
\text { Min }\end{array}$ & $\begin{array}{l}1.0 \text { VII, VIII } \\
0.7 \text { II }\end{array}$ & $\begin{aligned} 0.3 & \text { II } \\
-0.2 & \text { VIII }\end{aligned}$ & $\begin{array}{l}1.9 \mathrm{VII}, \mathrm{VIII} \\
0.9 \mathrm{I}\end{array}$ & $\begin{array}{l}-2.1 \text { VII, VIII } \\
-0.6 \text { I }\end{array}$ \\
\hline $\begin{array}{l}\text { Scarce } \\
\text { development }\end{array}$ & $\begin{array}{l}\text { Max } \\
\text { Min }\end{array}$ & $\begin{array}{l}0.5 \text { VIII, IX } \\
0.3 \text { III }\end{array}$ & $\begin{array}{l}0.1 \mathrm{IV}, \mathrm{V} \\
-0.04 \mathrm{X}\end{array}$ & $\begin{array}{l}1.2 \mathrm{VII} \\
0.5 \mathrm{I} .\end{array}$ & $\begin{array}{l}-1.2 \text { VII, VIII } \\
-0.4 \text { I }\end{array}$ \\
\hline $\begin{array}{l}\text { Park } \\
\text { complexes }\end{array}$ & $\begin{array}{l}\text { Max } \\
\text { Min }\end{array}$ & $\begin{array}{l}0.6 \mathrm{VI}, \mathrm{VII} \\
0.5 \mathrm{XII}\end{array}$ & $\begin{array}{l}0.6 \mathrm{IV} \\
0.3 \mathrm{X}\end{array}$ & $\begin{array}{l}1.3 \mathrm{VII} \\
0.7 \mathrm{I}\end{array}$ & $\begin{array}{l}-0.9 \text { VIII, IX } \\
-0.2 \text { II }\end{array}$ \\
\hline
\end{tabular}


Table 3

Sinusoids of daily air temperature differences between dense (1), scarce (2) building development and area open from the NE (3) with relation to SW suburbs of the town (July 1969)

\begin{tabular}{l|c|c|c}
\hline \multicolumn{1}{c|}{ Type of area } & & $\Delta y=a+b \sin \left(-\frac{2 \pi}{24} t+c\right)$ & $R$ \\
\hline Dense development & 1 & $\Delta T=0.854+1.776 \sin (0.262 t+1.382)$ & 0.93 \\
Scarce development & 2 & $\Delta T=0.271+0.890 \sin (0.262 t+1.588)$ & 0.86 \\
Area open from the NE & 3 & $\Delta T=0.186+0.489 \sin (0.262 t-2.358)$ & 0.74 \\
\hline
\end{tabular}

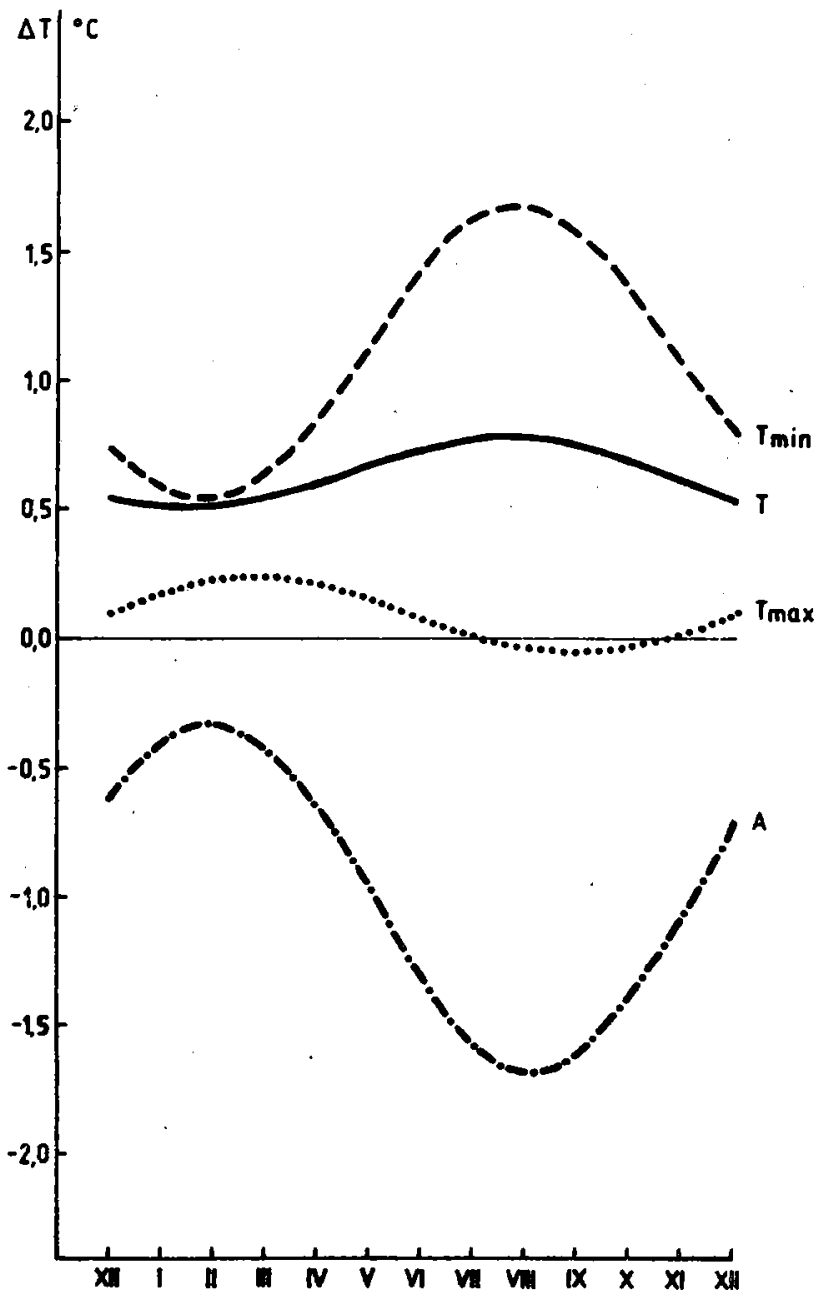

Fig. 1. Sinusoids of annual changes of difference of average $(\Delta T)$, maximum $\left(\Delta T_{\max }\right)$, minimum $\left(\Delta T_{\min }\right)$ air temperature and daily temperature amplitude $(\Delta A)$ between the town and its vicinity 


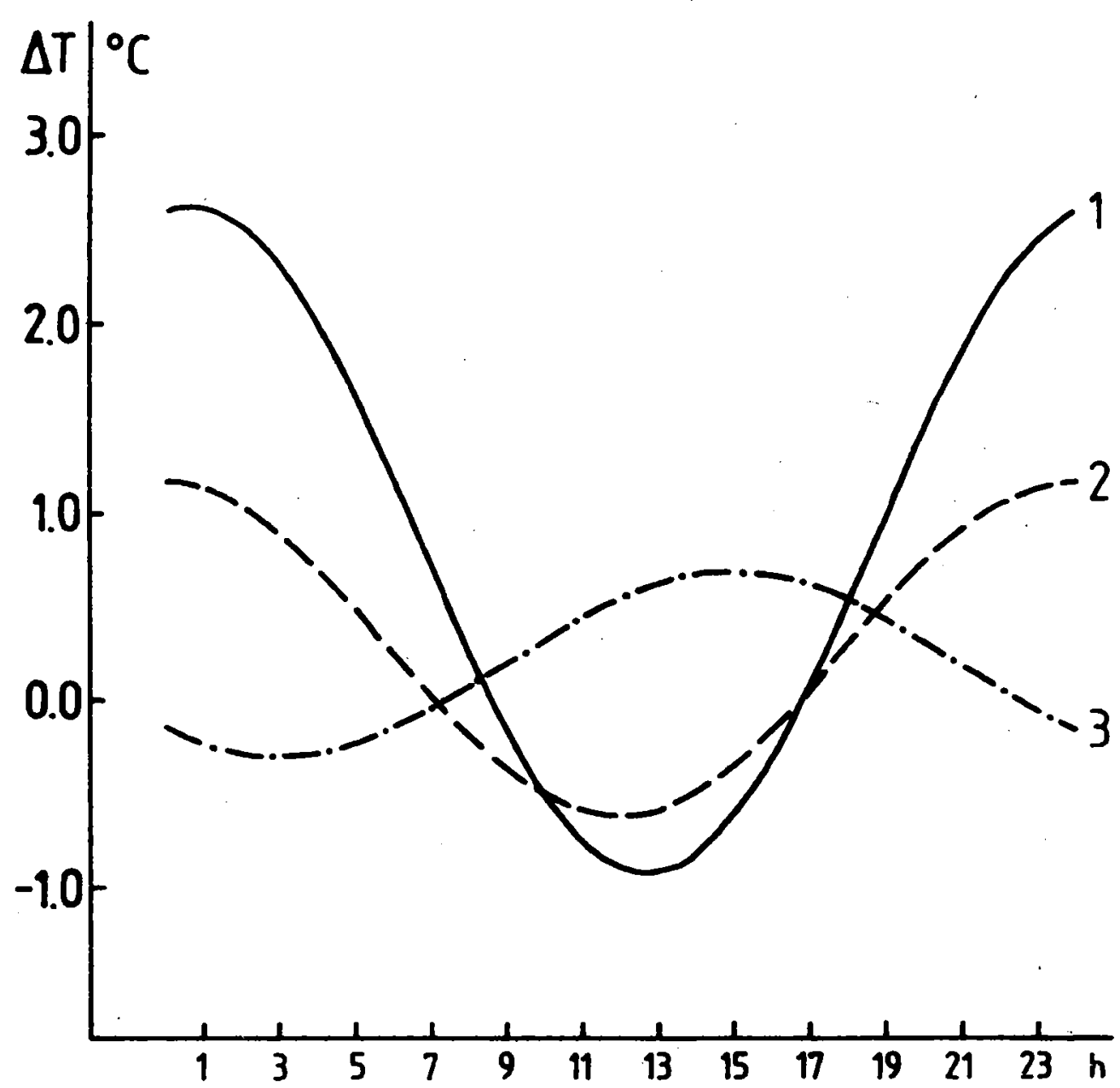

Fig. 2. Sinusoids of daily changes of differences of air temperature $(\Delta T)$ between the town and its vicinity $(1-$ dense building development, 2 - scarce building development, 3 - area open from the NE)

daily temperature amplitude $(\Delta A)$ are negative irrespective of the type of active surface in the town. The maximum temperature is an exception, because its difference $\left(\Delta T_{\max }\right)$ changes its sign from positive during winter and spring months to negative in the summer and autumn period. Thus, the town air temperature increases constantly, while the mean daily temperature amplitude decreases. Negative differences of maximum temperature, occurring during summer in a densely built-up area and in the autumn in scarce building development, prove that a slight "cold island" occurs in the town during the day.

The air temperature field undergoes greatest annual changes due to the building development (from $0.5^{\circ} \mathrm{C}$ in January - scarce building development to $1.9^{\circ} \mathrm{C}$ in July and August - dense building development) at night during 
the daily minimum, and smallest changes (from $-0.2^{\circ} \mathrm{C}$ in August - dense building development to $0.6^{\circ} \mathrm{C}$ in April - down town park) at maximum day temperature. An increase of air temperature is accompanied by an increase of air temperature difference between the town and its surroundings, especially at night. It reaches its maximum in July.

Lower heat radiation in urban areas results in lower daily fluctuations of air temperature in the town in comparison with its vicinity. This particularly concerns a dense building development (from $-0.6^{\circ} \mathrm{C}$ in January to $-2.1^{\circ} \mathrm{C}$ in July and August). Daily fluctuations of the air temperature field are less deformed by the urban area in scarce building development (from $-0.4^{\circ} \mathrm{C}$ to $-1.2^{\circ} \mathrm{C}$ ) and the deformation is smallest in park complexes (from $-0.2^{\circ} \mathrm{C}$ in February to $-0.9^{\circ} \mathrm{C}$ in August and September, Table 2).

Sinusoids of annual differences of air temperature amplitudes for the entire town are most strongly affected by the building development which finds confirmation in results obtained from $-0.3^{\circ} \mathrm{C}$ in February to $-1.7^{\circ} \mathrm{C}$ in August).

Sinusoids of annual changes of temperature differences determined for dense and scarce building development, and for park areas with respect to the surrounding prove that there is a dependence between temperature amplitude and type of active surface. Dense building development and park area in the downtown exhibit greatest deviations from Warsaw's average thermal conditions. Dense building development is characterized by the highest minimum temperature (up to $1.9^{\circ} \mathrm{C}$ ) and the lowest daily amplitude (up to $-2.1^{\circ} \mathrm{C}$ ) in relation to the surroundings. Urban green areas, on the other hand, are distinguishable by the highest maximum temperature (up to $0.6^{\circ} \mathrm{C}$ ) and the highest temperature amplitude (up to $-0.9^{\circ} \mathrm{C}$ ) in relation to the surroundings.

Diurnal course of temperature differences changes in the opposite direction to values of air temperature, which can be seen on the example of the month of July 1969 (Table 3, Fig. 2). Much greater changes occur at night (from $1.2^{\circ} \mathrm{C}$ in scarce building development to $2.6^{\circ} \mathrm{C}$ in dense building development) at lower values of air temperature than during the day - at higher values of air temperature (from $-0.6^{\circ} \mathrm{C}$ in scarce building development to $-1.0^{\circ} \mathrm{C}$ in dense building development). It should be mentioned that the difference changes its sign during the day from positive in the evening, at night and in the morning to negative before noon, at noon and in the afternoon. Thus, the built-up area produces a cooling effect at day and heating effect at night on its closest surroundings.

Intersections of the curve describing air temperature differences between town and its vicinity with the line $\Delta T=0$ define times of occurance and disappearance of the urban heat island. In summer the heat island appears nearly simultaneously in dense and scarce building development, i.e. about 5 p.m., whereas it disappears earlier in scarce building development - at 7 a.m., than in dense building development - at 9 a.m.. The greatest 
increment of temperature difference $\left(2.6^{\circ} \mathrm{C}\right)$ occurs 4 hours after sunset $(12$ p.m. -1 a.m.).

In order to give a full description of thermal conditions in Warsaw, a diurnal distribution of temperature differences between an open area in the north-east part of the town and south-west suburb is given. North-east areas are cooler at night and warmer during the day in comparison with the southwest suburb.

Regression parabolas were determined in order to find out threshold values of the particular meteorological parameters, at which differences of the state of the atmosphere between town and its vicinity are greatest or smallest. Here are examples of parabolic dependencies of differences of minimum $\left(\Delta T_{\min }\right)$, mean daily $(\Delta T)$, maximum $\left(\Delta T_{\max }\right)$ and amplitude $(\Delta A)$ of air temperature between town and its vicinity with respect to the values of corresponding characteristics for the vicinity in the warm half-year, cold half-year and the whole year (Table 4, Fig. 3).

Sectors of parabolas describe highest deformations of the air temperature field in the town. This indicates that the influence of the artificial base on the thermal state of the atmosphere depends on the season of the year. This influence is usually greater in the warm half-year than in the cold half-year.

The urban heat island is especially pronounced when the air temperature outside town is equal to $13 \div 16^{\circ} \mathrm{C}$. Differences between town and suburbs decrease at lower and higher temperatures. In the cold half-year the urban heat island is least pronounced at the temperature of $-2 \div 1^{\circ} \mathrm{C}$, and most pronounced at a temperature drop below $-10^{\circ} \mathrm{C}$.

Table 4

Equations of regression parabolas of differences of average $(\Delta T)$, maximum $\left(\Delta T_{\max }\right)$ minimum $\left(\Delta T_{\min }\right)$ air temperature and daily temperature amplitude $(\Delta A)$ between the town and suburbs with relation to the vicinity $(1961-1965)$

\begin{tabular}{|c|c|c|c|c|c|}
\hline \multirow{2}{*}{$\begin{array}{r}\text { Months } \\
X-\text { III }\end{array}$} & \multicolumn{4}{|c|}{$y=a x^{2}+b x+c$} & $R$ \\
\hline & $\begin{array}{l}\Delta T \\
\Delta T_{\operatorname{mux}} \\
\Delta T_{\min } \\
\Delta A\end{array}$ & $\begin{array}{l}=0.0030 T^{2} \\
=-0.0017 T_{\max }^{2} \\
=0.0051 T_{\min }^{2} \\
=-0.0279 A^{2}\end{array}$ & $\begin{array}{l}-0.0061 T \\
-0.0019 T_{\max } \\
+0.0239 T_{\min } \\
+0.1510 \mathrm{~A}\end{array}$ & $\begin{array}{l}+0.41 \\
+0.31 \\
+0.65 \\
-0.44\end{array}$ & $\begin{array}{r}0.60 \\
-0.75 \\
0.50 \\
-0.76\end{array}$ \\
\hline IV-IX & $\begin{array}{l}\Delta T \\
\Delta T_{\max } \\
\Delta T_{\min } \\
\Delta A\end{array}$ & $\begin{array}{l}=-0.0025 T^{2} \\
=-0.0001 T_{\max }^{2} \\
=-0.0032 T_{\min }^{2} \\
=0.0064 A^{2}\end{array}$ & $\begin{array}{l}+0.0693 T^{\prime} \\
-0.0059 T_{\max } \\
+0.1054 T_{\min } \\
-0.3717 \mathrm{~A}\end{array}$ & $\begin{array}{l}+0.21 \\
+0.31 \\
+0.53 \\
+2.00\end{array}$ & $\begin{array}{r}-0.26 \\
-0.14 \\
-0.52 \\
0.49\end{array}$ \\
\hline $\mathrm{I}-\mathrm{XII}$ & $\begin{array}{l}\Delta T \\
\Delta T_{\max } \\
\Delta T_{\min } \\
\Delta A\end{array}$ & $\begin{array}{l}=0.0008 T^{2} \\
=0.0002 T_{\max }^{2} \\
=0.0036 T_{\min }^{2} \\
=-0.0037 A^{2}\end{array}$ & $\begin{array}{l}-0.0021 T \\
-0.0095 T_{\max } \\
-0.0147 T_{\min } \\
-0.0884 \mathrm{~A}\end{array}$ & $\begin{array}{l}+0.49 \\
+0.28 \\
+0.70 \\
+0.22\end{array}$ & $\begin{array}{l}0.42 \\
0.33 \\
0.64 \\
0.67\end{array}$ \\
\hline
\end{tabular}



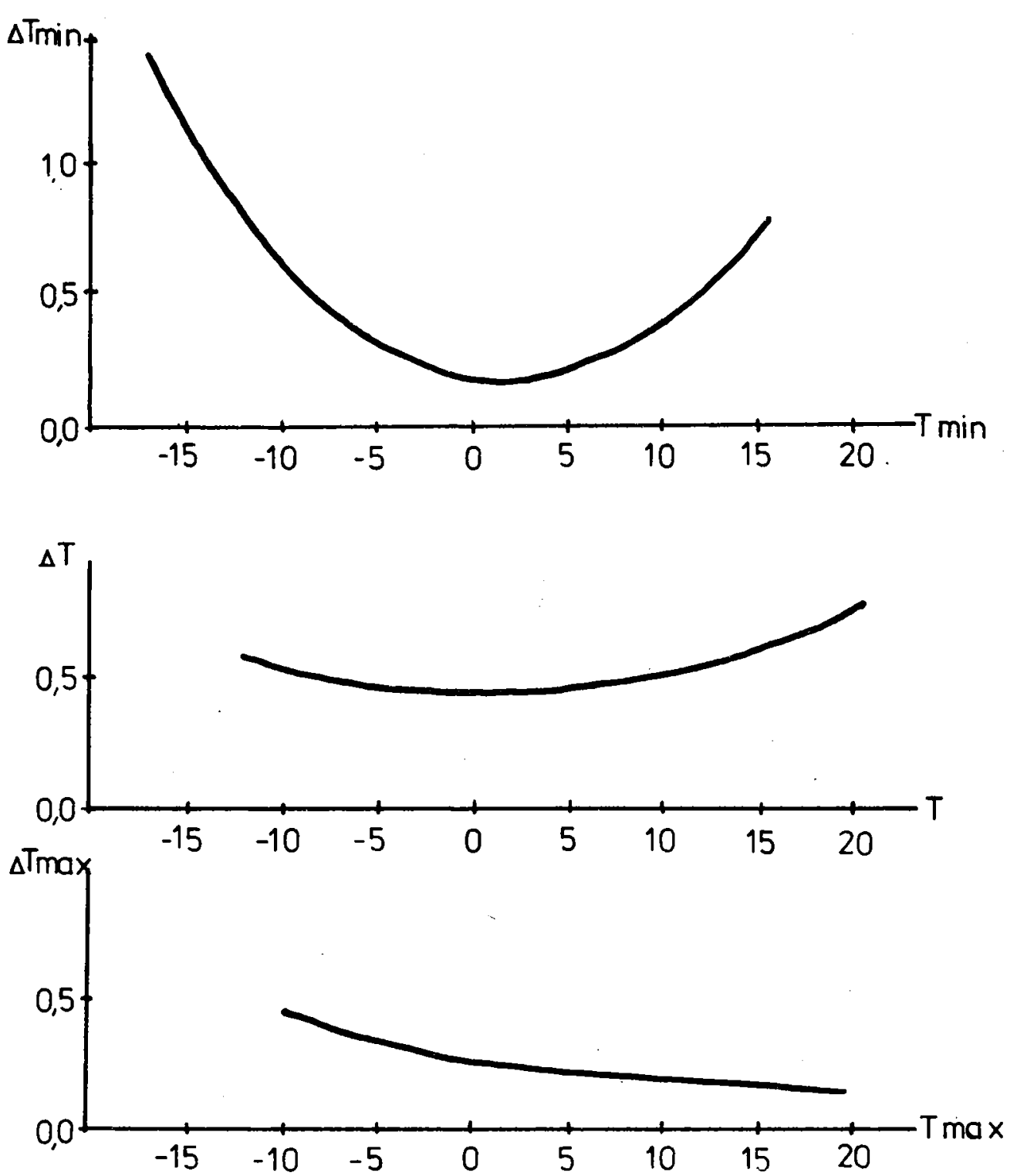

Fig. 3. Parabolic dependencies of differences of average minimum $\left(\Delta T_{\min }\right)$, daily $(\Delta T)$ and maximum $\left(\Delta T_{\max }\right)$ air temperature between the town and its vicinity on the temperature of surroundings 

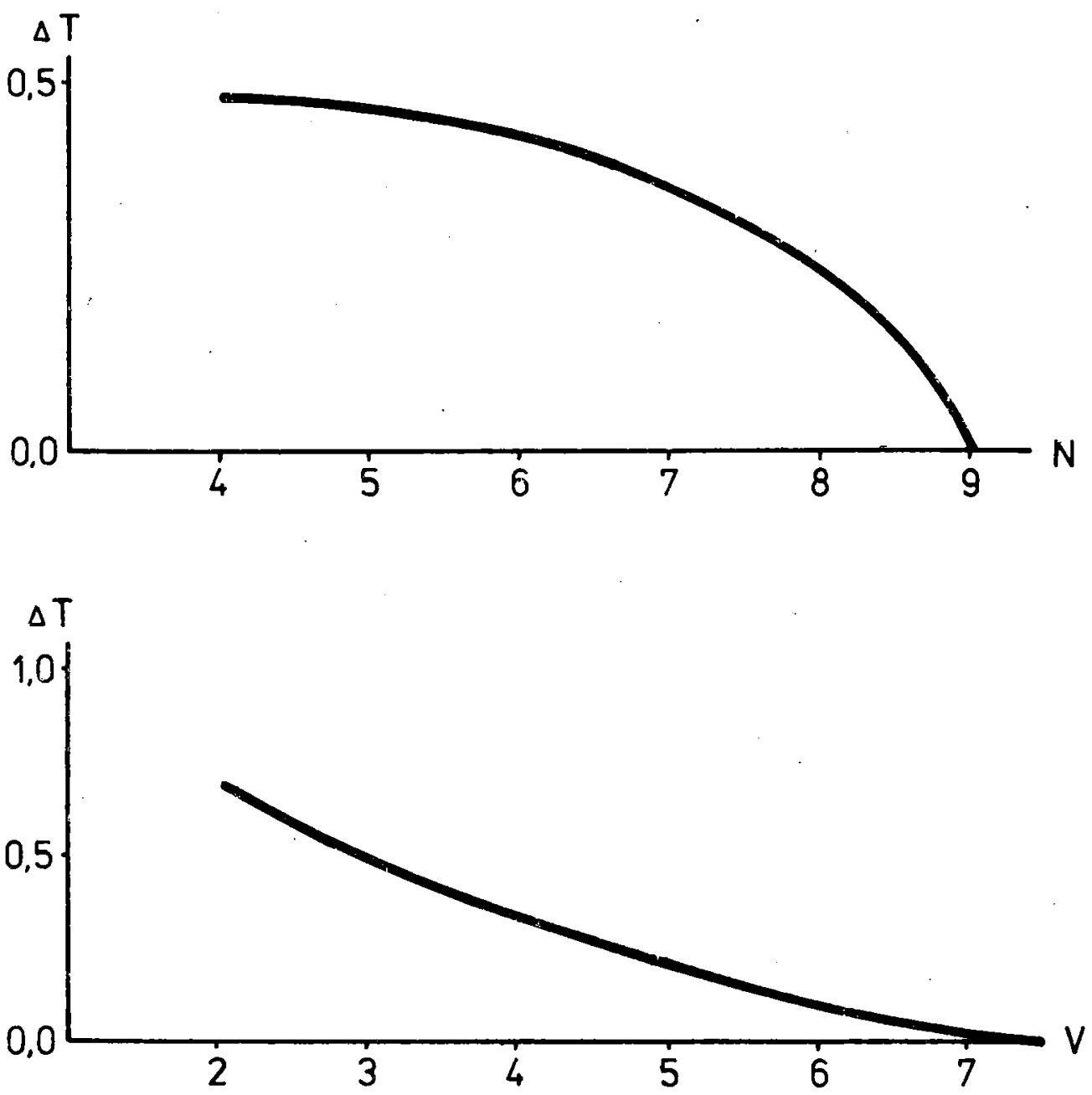

Fig. 4. Parabolic dependence of the temperature difference $(\Delta T)$ between the town and its vicinity on cloudiness $(\mathrm{N})$ and wind velocity (v)

The influence of other meteorological elements on the heat island was determined similarily. The effect of cloudiness and wind velocity on the urban heat island is expressed by empirical formulae and diagrams (Fig. 4). Cloudiness

$$
\begin{array}{rll}
\text { X- III } & \Delta T=-0.0167 \mathrm{~N}^{2}+0.1612 \mathrm{~N}+0.005 & R=-0.29 \\
\text { IV_IX } & \Delta T=0.0417 \mathrm{~N}^{2}+0.4365 \mathrm{~N}-0.649 & R=-0.32 \\
\text { I-XII } & \Delta T=-0.0189 \mathrm{~N}^{2}+0.1653 \mathrm{~N}+0.119 & R=-0.42
\end{array}
$$

wind velocity

$$
\begin{array}{cll}
\text { X-III } & \Delta T=0.0296 \mathrm{v}^{2}-0.4049 \mathrm{v}+1.458 & R=0.46 \\
\text { IV-IX } & \Delta T=0.0184 \mathrm{v}^{2}-0.2322 \mathrm{v}+1.031 & R=0.29 \\
\text { I-XII } & \Delta T=0.0134 \mathrm{v}^{2}-0.2538 \mathrm{v}+1.148 & R=0.49
\end{array}
$$


These parabolas have the following extremes:

$\begin{array}{rcccc} & N & \Delta T & v & \Delta T \\ \text { X- III } & 4.8 & 0.35 & 2.5 & 0.6 \\ \text { IV- IX } & 5.2 & 0.49 & 2.1 & 0.7 \\ \text { I--XII } & 4.4 & 0.48 & 2.1 & 0.7\end{array}$

The analysis proves that the temperature difference between the town and its vicinity $(\Delta T=0)$ disappears at wind velocity equal to approximately $7 \mathrm{~m} / \mathrm{s}$ and cloudiness equal to about $90 \%$; while greatest differences $\left(0.4-0.5^{\circ} \mathrm{C}\right)$ occur at cloudiness equal to about $50 \%$ and $\left(0.6-0.7^{\circ} \mathrm{C}\right)$ at wind velocity in the range of $2-2.5 \mathrm{~m} / \mathrm{s}$.

Further research was aimed at the determination of the influence of temperature, cloudiness and wind velocity on the urban heat island. Equations of regression hyperplanes were found for both half-years and whole year:

$$
\begin{array}{rll}
\text { X- III } & \Delta T=-0.0186 \mathrm{~T}-0.0687 \mathrm{~N}-0.1479 \mathrm{v}+1.448 & R=0.58 \\
\text { IV-IX } & \Delta T=-0.0105 \mathrm{~T}-0.0585 \mathrm{~N}-0.1082 \mathrm{v}+1.329 & R=0.38 \\
\text { I-XII } & \Delta T=-0.0077 \mathrm{~T}-0.0762 \mathrm{~N}-0.1359 \mathrm{v}+1.466 & R=0.56
\end{array}
$$

Negative regression coefficients indicate that,regardless of the season of the year, temperature differences $(\Delta T)$ between the town and its vicinity decrease with an increase of air temperature, cloudiness and wind velocity.

Wind velocity is distinguishable within the group of investigated meteorological variables. It has the greatest influence on the value of differences, which is confirmed by greatest coefficients of partial correlation: cold half-year -0.51 , warm half-year -0.28 , at the level of confidence equal to $95 \%$. When the influence of air temperature and cloudiness is eliminated, an increase of wind velocity outside town by $1 \mathrm{~m} / \mathrm{s}$ corresponds to a $0.11-0.15^{\circ} \mathrm{C}$ decrease of the average air temperature $(\Delta T)$.

The relationships between building development and thermal conditions result mainly from the dominating role of the increased active area in town. The active area in town, consisting of several levels, absorbs and accumulates large amounts of heat during the day and emits it at night. Heat accumulation of buildings and its intensive carrying away (convection, turbulence) to higher layers of the atmosphere is a reason for slower warming up of the town during morning hours with respect to the vicinity.

The daily heat island enhances most strongly in winter in the downtown (in dense building development and park complexes) at rather low maximum air temperature. Most probably this is due to the influence of the large active surface in town at small insolation, albedo and convection.

At night the town cools down much more slowly in comparison with its surroundings, which can be seen on the example of differences of minimum temperature as well as the night, hourly distribution of differences between town and its vicinity. The occurrence of the night island in the town is due to the thermal influence of the building (long wave radiation of walls, 
sidewalks, streets etc.). At night the town is much warmer (by $2^{\circ} \mathrm{C}$ in average values of minimum temperature and by $7^{\circ} \mathrm{C}$ during particular days) than its surroundings as a result of additionally accumulated heat by the base (and buildings) and lesser heat radiation (high concentration of dust and $\mathrm{CO}_{2}$, greater cloud cover). The thermal effect of building development (with artificial heat sources) is especially distinct in winter at low air temperatures. For this reason the urban heat island is observed during all twenty-four hours, while in summer the heat island becomes more distinct from the evening to the morning. The heating effect of the urban area is small around noon.

It may be possible that daily and annual heat island changes can be different on higher levels - above the town. In the afternoon the air above the town can warm up more quickly than the surroundings due to a more intensive process of heat abstraction by means of convection and mechanical turbulence.

These relationships between the artificial base and state of the atmosphere with respect to the season of the year, hour of day and meteorological conditions can be applied in forecasts of man-made changes of the climate. If values of meteorological elements measured out of town are inserted in adequate formulae (equations of regression parabolas, sinusoids and hyperplanes), then air temperature differences between town and its surroundings can be estimated. Therefore, there is a possibility of forecasting the air temperature, for example in districts, developed towns or planned towns, settlements in which meteorological measurements have not been made as yet.

Results obtained for Warsaw concerning the deformation of the air temperature field due to building development are consistent with data from literature (Chandler 1965; Hess 1968; Landsberg 1970; Kossowska-Cezak 1973, 1976; Oke 1978; Lewińska et al, 1982; Kłysik et al, 1984; Fortini 1985).

\section{REFERENCES}

$\mathrm{Ch}$ a n d l e r, T., 1965, Climate of London, Heffer and Sons Ltd. Cambridge.

Forti.ni, J., 1985, „Wpływ rzeźby terenu i zabudowy mieszkaniowej na ksztaltowanie się warunków klimatu lokalnego" (The effect of earth relief and building development on the formation of local climate conditions), IKŚ, Warszawa.

H e s s, M., 1968, „Klimat terytorium miasta Krakowa” (Climate of the urban area of Cracov), Folia Geographica (ser. geogr. - Phys.), Vol. I, Kraków.

K łysik, K., K ożuch owski, K., Tarajk ow ska, M., 1984, „Zasady klasyfikacji klimatu $\mathrm{i}$ oceny bioklimatu terenów miejskich" (Principles of climate classification and bioclimate evaluation in urban areas), Materiały I Ogólnopolskiej Konferencji nt. Klimat i bioklimat miast, Lódź, 22-24 listopada 1984, Uniwersytet Łódzki, Łódź.

K os sowska, U., 1973, „Osobliwości klimatu wielkomiejskiego na przykładzie Warszawy” (Pecularities of urban climate on the example of Warsaw), Prace i Studia IG UW, No. 12, Klimatologia, No. 7. 
K ossowska-Cezak, U., 1976, „Zmiany roczne różnic temperatury powietrza między śródmieściem i peryferiami Warszawy" (Annual changes of air temperature differences between the centre and suburbs of Warsaw), Prace i Studia IG $U W$, No. 18, Klimatologia, No. 8.

L a n d s berg, H. E., 1970, "Climates and urban planning", WMO Technical Note No. 108, Geneva.

L e w i ńsk a, J., Z gu d, K., B a ścik, J., Bartosik, J., C z e rwienie c, M., 1982, Wpływ miasta na klimat lokalny (na przykładzie aglomeracji krakowskiej) (The influence of town development on local climate: the example of the Cracow agglomeration), IKŚ, Warszawa.

O k e, T.R., 1978, Boundary layer climates, Methuen, London.

S t opa-B or yczka, M., K opacz-Lembowicz, M., Koss owska-Cezak, U., R y c z y w o lska, E., W a we r, J., 1984, Badania wpływu zabudowy na klimat lokalny w Warszawie" (Studies on the influence of land development on the local climate in Warsaw), Mat. I Ogólnopolskiej Konferencji nt. Klimat i bioklimat miast, Lódź, 22-24 listopada 1984, Uniwersytet Lódzki, Łódź.

S t opa-B or yczka, M., K o pacz-Le mbow icz, M., Koss ow ska-Cezak, U., M ierzwiński, B., W a wer, J., 1986, "Deformation of Fields of Meteorological Elements under the Influence of Buildings", Miscellanea Geographica, Warszawa.

S t opa-B or yczka, M., K o pacz-Le m b ow icz, M., B or yczka, J., 1986, „Wpływ miasta na pola zmiennych meteorologicznych" (The influence of town development on fields of meteorological variables), Mat. z Sympozjum RWPG nt. Badania i metody ksztaltowania ekosystemów miejskich $i$ terenów rekreacyjnych, Jabłonna, 22-27 września 1986. 
